\title{
The Mediating Effects of Time Management on Accounting Students' Perception of Time Pressure, Satisfaction with the Major, and Academic Performance
}

\author{
David P. Donnelly \\ The University of Missouri - Kansas City \\ Stacy E. Kovar \\ Kansas State University \\ Dann G. Fisher \\ Kansas State University
}

\begin{abstract}
We model a relationship between accounting students' individual characteristics (locus of control and personal need for structure) and satisfaction with the accounting major and academic performance. We hypothesize that perception of time pressure on exams, time management behaviors, and perceived control of time mediate the relationship. We find that locus of control and desire for structure influence time management behavior. These behaviors, in turn, influence perceived control of time and satisfaction, but not performance. Our results suggest potential benefit of counseling accounting students on time management behaviors.
\end{abstract}

Keywords: time management, accounting education, time pressure, locus of control, personal need for structure, structural equation modeling

\section{INTRODUCTION}

Accounting is a very demanding major. Reading and problem assignments, group work, presentations, quizzes, exams and extracurricular activities keep students incredibly busy. Those students who have part-time or full-time jobs are further taxed. The 2001 report by the Higher Education Research Institute at the University of California at Los Angeles revealed that 44 percent (a 12 percent increase over the prior year) of college freshmen feel overwhelmed by everything they had to do (Bartlett, 2002). However, contrary to expectations that increasing outside demands would lead to poorer performance, Ackerman and Gross (2003) found that students with less free time performed better academically than those with more free time. Based on these results, they suggest that busy students may have or be forced to develop better time-management skills. Similarly, Macon, Shahani, Dipboye and Phillips (1990) suggest that proper time allocation reduces stress and creates positive academic experiences and performance. Given, the increasing demands encountered by current college students, it is important for 
educators to examine the relationship between student time-management skills and their performance and satisfaction with their academic experience.

An understanding of this relationship for accounting students is important for two reasons. First, good time management practices are important for accounting majors because they face academic demands that other business majors do not. The majority of accounting majors indicate that they plan to sit for a certification exam (Bierstaker, Howe and Seol, 2004). If the student plans to sit for the CPA exam, he or she will generally need to complete 150 hours. This requires either attending graduate school or pursuing a dual-major. When the time comes, accounting students have the added demands of preparing for the certification exam. Understanding the relationship between personality characteristics and time management skills and how they influence success in the accounting major should improve the ability of faculty to advise students.

Second, learning sufficient time management skills prior to entering the profession is critical because accounting is a very time-sensitive, demanding profession. Noting that subjects worked an average of 63 hours per week during busy season, Sweeney and Summers (2002) found that accountants in public practice experienced extremely high burnout levels. Citing time budget restrictions, numerous authors have examined the effect of time pressure on the performance of audit (Braun 2000; Brown \& Solomon, 1992; Choo, 1995; Glover, 1997; McDaniel, 1990; Otley and Pierce, 1996; Ponemon, 1992; Waggoner and Cashell, 1991) and tax (Newmark and Karim, 2002; Spilker, 1995; Spilker and Prawitt, 1997) functions. The primary finding of this research is that performance tends to decline as time pressure intensifies. These studies suggest that the ability to work under time pressure and to manage one's time is critical to success in the profession. Macan (1994) found that students who are better able to manage their time perceive themselves to be a good fit with their major and, subsequently, with their chosen profession. Taken together, these studies suggest that development of the requisite time management skills during the education process is essential for and perhaps a predictor of success in the profession.

The purpose of this study is to introduce a cognitive model that explains the importance of structure and control on accounting student outcomes. The model suggests that individual characteristics (locus of control and personal need for structure) predict two identified outcome measures (a student's satisfaction with the accounting major and his or her academic performance). However, the effects of personal characteristics are mediated by two factors, the individual's perception of time pressure and their time management behaviors. The first factor, time pressure, measures the student's perception of time related stress while performing a specific task, e.g. taking an exam. The second factor, time management behaviors, measures the student's perceived importance in managing his/her time. It is hypothesized that the student's perception of time pressure during test taking will influence his/her performance and satisfaction with the accounting major. Similarly, it is hypothesized that the use of time management behaviors influences a student's perceived control over time which in turn impacts the identified outcome variables.

The results of our study confirm the multidimensionality of time management behavior (Macan, Shahani, Dipboye and Phillips, 1990; Macan, 1994). Use of the Time Management Behavior Scale (Macan, Shashani, Dipboye and Phillips, 1990) reveals three distinct dimensions to time management behavior - setting goals and priorities, mechanics (making lists and schedules), and preference for organization. The more internal a student's locus of control, the more likely he or she was to engage in these time management behaviors. Furthermore, the greater the student's desire for structure, the more likely he or she was to engage in these time management behaviors. These time management behaviors were not, however, related to the individual's disdain for disorganization/response to lack of structure.

Consistent with prior research (Macon, 1994), the higher a student's preference for organization and the more willing he or she is to set goals and prioritize tasks, the higher is his or her perceived control of time. The mechanics of time management behavior (making lists and schedules) was not found, however, to influence perceived control of time.

Both perceived control of time and locus of control have significant relationships with satisfaction with the accounting major, but not with performance, while time pressure on exams, which was also related to locus of control, had a significant relationship with performance. The implications of these 
results are discussed in the conclusion of the paper. The paper proceeds in the following manner. The next section introduces our research model. This is followed by a discussion of our methodology and analysis. The final section consists of a summary and discussion.

\section{RESEARCH MODEL}

The theoretical model used in the current study identifies two individual characteristics (locus of control and personal need for structure) hypothesized to directly affect two identified outcome measures (satisfaction with the accounting major and academic performance). The effects of personal characteristics are mediated by two factors, time pressure on exams and the student's time management behaviors. It is hypothesized that the use of time management behaviors influences a student's perceived control over time which in turn impacts the identified outcome variables. The full theoretical model is presented in Figure 1. Each link in the model is discussed below.

\section{FIGURE 1}

\section{HYPOTHESIZED MODEL}

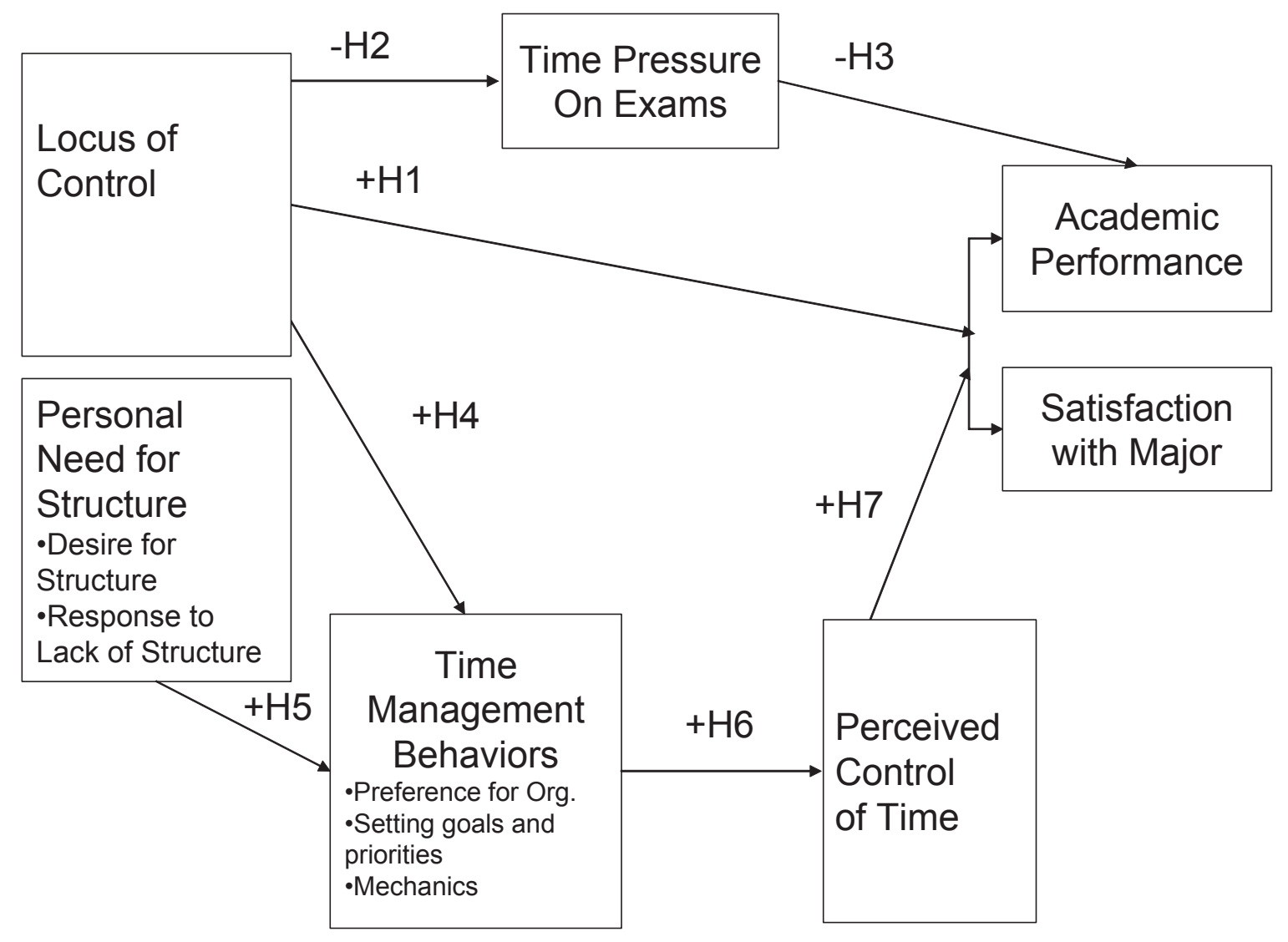

\section{Locus of Control}

Locus of control is a personality trait first developed by Rotter (1966) as an extension of social learning theory (Rotter, 1954). This concept measures an individual's propensity to attribute the cause of events to either internal or external factors. Individuals classified as internals believe that they control events through their own actions. Externals believe that events or outcomes are controlled by external forces and not by their own personal behavior (Spector, 1982).

Prior research has found that the locus of control personality trait is significantly related to numerous specific behaviors. Internals have been found to exert greater effort than externals when it is believed that 
effort leads to rewards (Spector, 1982; Majumder, MacDonald \& Greever, 1977; Phares, 1976). Internals have been shown to exhibit better learning and problem-solving skills (Phares, 1976; Wolk \& DuCette 1974; DuCette \& Wolk 1973), and to use information better in complex problem-solving situations (Phares, 1968). Also, internals demonstrate greater job satisfaction than externals (Spector, 1982). This leads to the following hypotheses.

\section{H1A: Internal locus of control is positively related to satisfaction with the accounting major.}

\section{H1B: Internal locus of control is related to academic performance.}

It is very common in accounting courses for students to experience varying degrees of time pressure through imposed time constraints on exams and class projects. This practice has been generally accepted based on arguments that time consciousness and the ability to perform under time pressure are critical attributes for individuals entering the accounting profession. Anderson-Gough, Grey and Robson (2001) suggest that time-management and time-consciousness are fundamental aspects of securing and developing a professional identity. Accounting graduates recognize that passing the CPA examination is a requirement for professional socialization. The role of the professional exam is generally recognized to create a barrier to others entering the jurisdiction of the profession (Abbott, 1998). Thus, the professional socialization of accounting graduates is dependent on their capacity to deal with the time constraints of the examination process itself (Anderson-Gough, Grey and Robinson, 2001).

Time pressure is an externally imposed condition that impairs the individual's confidence in his/her ability to perform an assigned task. When time becomes an externally imposed restriction it can produce demand stress if the individual perceives the task assigned cannot be completed. Several studies have provided support for the notion that locus of control personality characteristics moderate the adverse effects of occupational stress (Rahim \& Psenicka, 1996; Cummins, 1988). Specifically, internal locus of control has been associated with lower levels of perceived stress (Bernardi, 1998; Kobasa, Maddi and Kahn, 1982), while external locus of control is positively correlated with perceived stress (Evans \& Coman, 1993; Jennings, 1990). This leads to the following hypothesis.

\section{H2: Internal locus of control is negatively related to perception of time pressure.}

Prior research examining the impact of time pressure on performance has shown that individuals will work faster when the time allowed to complete the task is shortened (Bassett, 1979; Latham \& Locke, 1975). The quality of performance, however, will decrease when the time pressure becomes too severe (Kelly \& McGrath, 1985; Peters, O'Conner, Pooyon and Quick, 1984; McDaniel, 1990; Braun, 2000). Andrews \& Farris (1972) found that performance was related to the individual's perceived time pressure. When perceived time pressure is high, internal demand stress is generated which reduces motivation and performance (Schuler, 1980). This leads to the following hypothesis.

\section{H3: Level of perceived time pressure on exams is negatively related to academic performance.}

The relationship between time management behaviors and locus of control has not been directly examined in prior research. However, the results of several studies suggest there is a relationship between an individual's locus of control and their time management behaviors. Phares (1968) found that internals used more efficient strategies in a free recall experiment and structured information better than externals. Similarly, Lefcourt \& Wine (1969) found that internals exhibit higher levels of incidental learning which has been interpreted to suggest that internals have a more attentive and organized cognitive system (DuCette \& Wolk, 1973; Wolk \& DuCette, 1974). Other studies have found that internals set higher goals (Yukl \& Latham, 1978) and develop higher expectancies in environments where effort leads to rewards (Lawler, 1971). Anderson \& Schneier (1978), in a study of college students, found that internals are more task oriented and more likely to emerge as group leaders. These earlier findings suggest that individuals 
with an internal locus of control have a higher propensity for setting goals and priorities and a preference for organization, two dimensions of time management behavior (Macan, Shashani, Dipboye and Phillips, 1990). This leads to the following hypothesis.

\section{H4: Internal locus of control is positively related to time management behavior.}

\section{Personal Need for Structure}

Neuberg \& Newsom (1993) defined the need for structure as the desire to create simple cognitive structures that serve to reduce the information to which one must attend. According to Neuberg \& Newsom, the desire for simple structure leads one to prefer a simple, tightly organized life. Persons with a strong desire for structure will experience discomfort when they perceive lack of structure or ambiguity to exist.

Neuberg \& Newsom employ the Personal Need for Structure (PNS) scale (Thompson, Naccarato and Parker, 1989, 1992) to assess need for structure, suggesting that the construct is composed of two related but conceptually distinct factors - desire for structure and the response to a lack of structure. The desire for structure captures the extent to which a person prefers to have structure in his or her life. Response to lack of structure examines the level of discomfort that the person feels when facing unstructured or ambiguous situations.

Persons who dislike and are made to feel discomfort by ambiguous, unstructured situations should be more likely to engage in behaviors that add organization and clarity to their environments. Prior research has found the personal need for structure to be highly related to an intolerance of ambiguity (Leone, Wallace and Modglin, 1999). Thus, individuals with high PNS are likely to use time management behaviors to add structure to their environments. These behaviors would serve to mediate the negative effects associated with an unstructured environment. This notion is somewhat supported by earlier studies that found that students high in PNS were more likely to complete course requirements early in order to minimize the discomfort that occurs from lack of closure (Neuberg \& Newsom, 1993). This leads to the following hypothesis.

H5: Personal need for structure is positively related to time management behavior.

\section{Time Management Behavior}

Time management is generally defined as the activities associated with prioritizing tasks in order to achieve individual's wants or needs (Lakein, 1973). Macan, Shashani, Dipboye and Phillips (1990) operationalized this definition by identifying three factors indicating time management behaviors: goal setting, time management mechanics (e.g. making lists), and a preference for organization. These behaviors are believed to lead to greater perceived control of time, which results in improved performance outcomes. However, little research has been conducted to examine this relationship. Macan (1994) surveyed 353 employees from two organizations (a public social service agency and a department of corrections organization) and found a significant relationship between employee time management behaviors and their perceived control of time. In a study of 341 students Macan (1994) found the relationship between time management behaviors and perceived control of time to be insignificant. These results suggest that the strength of this relationship may be environment specific. Given the strong theoretical argument for a positive relationship between time management behaviors and perceived control of time the following hypothesis is proposed.

\section{H6: Time management behavior is positively related to perceived control of time.}

Macan (1994) presents a process model of time management behavior. She posited that time management behaviors will influence an individual's tension, satisfaction and performance indirectly through perception of control over time. In our model, time management behavior mediates the effects of personal characteristics on an individual's satisfaction and performance. Specifically, we argue that 
students who engage in time management behaviors, and therefore have high perceptions of control over time, will experience greater levels of satisfaction with the accounting major and academic performance.

\section{H7A: Perception of control of time is positively related to satisfaction with the accounting major.}

\section{H7B: Perception of control of time is positively related to academic performance.}

\section{METHODOLOGY}

The hypotheses were tested with a sample of accounting students from a major Midwestern university. Students were given the survey instrument in an envelope and were asked to complete it outside of class. They were instructed to complete it individually, without discussing the content of the survey with other students. Students were given a small amount of extra credit for completing the instrument. The survey instrument was completed by 111 junior and senior accounting majors. Below we describe the variable measures used in the study.

\section{Time Management Behavior Scale}

Macan, Shashani, Dipboye and Phillips (1990) developed the Time Management Behavior Scale (TMBS) to measure the extent to which a person uses time management behaviors. The scale is not designed to assess the person's evaluation of the effectiveness or appropriateness of time management behaviors.

The 46-item TMBS (reproduced in Appendix A) consists of three factors - setting goals and priorities, mechanics, and preference for organization - that are found to be antecedents of a fourth factor - perceived control of time. Subjects respond to each item using a 5-point Likert-type scale from seldom true (1) to very often true (5). Negatively worded items are reverse scored.

The first factor, setting goals and priorities, consists of 15 items and assesses whether or not the person is willing to set goals and prioritize the tasks needed to achieve those goals. The second factor, mechanics, consists of 13 items and refers to typical time management behaviors such as planning, making lists, scheduling, writing reminder notes, etc. The third factor, preference for organization, consists of 13 items and refers to a general preference for organization of the workspace and in the approach to work tasks. The fourth factor, perceived control of time, consists of five items and reflects the person's beliefs that he or she can influence how time is spent. Cronbach's alphas for the measures were .84 for setting goals and priorities, .77 mechanics, .79 preference for organization and .56 perceived control of time. Each of these is a reasonable level of internal validity, with the exception of perceived control of time, which is not totally unacceptable given the exploratory nature of our study. However, results related to this variable should be interpreted with caution.

\section{Locus of Control}

Locus of control was measured using the 16-item Spector (1988) locus of control scale (reproduced in Appendix A). The Spector (1988) measure has been shown to possess a strong fit to work-related outcomes (Blau, 1993). Using such concepts as job satisfaction, organizational commitment, role stress, and leadership behavior, Spector (1988) found the locus of control measure to be significantly related to these outcomes. Respondents were asked to identify the relationships between reward/outcomes and causes using a seven-point Likert-type scale. Higher scores on the work locus of control scale indicate a greater degree of external personality, while lower scores are associated with internal traits. The instrument's reliability and validity have been deemed acceptable in prior research (e.g., Blau, 1993; Spector, 1988). In the current study, the measure exhibits similar levels of reliability with a Cronbach's alpha of .84 . 


\section{Personal Need for Structure}

Personal need for structure was measured using Neuberg \& Newsom's (1993) reduced, 11-item measure (reproduced in Appendix A). A factor analysis confirmed the dimensions of the scale as identified by Neuberg \& Newsom with four items measuring desire for structure and the remaining seven measuring response to lack of structure. Factor 1, measuring Desire for Structure, exhibits reasonable validity with an alpha of .70 as does Factor 2, measuring Response to Lack of Structure, with an alpha of .80 .

\section{Time Pressure on Tests}

Time pressure on tests was measured using four items that measured subjects' agreement with statements about their level of time pressure on tests. Items measuring this construct are listed in Appendix A. The measure exhibited reasonable levels of reliability, with a Cronbach's alpha of .83.

\section{Performance}

Subject's performance was measured by subjects overall GPA (as self-reported by the subject). Performance was also measured using GPA in accounting courses only (again, a self-reported measure). Results did not differ in any meaningful way from results using the overall GPA. Because fewer subjects were able to provide their accounting-only GPA, the results using the overall GPA are reported in the remainder of the paper.

\section{Satisfaction}

Satisfaction was measured in terms of the students' satisfaction with their academic major. The five items measuring this construct are listed in Appendix A. Each item measured subjects' agreement with a statement related to their academic major or the coursework related to it. The measure exhibited acceptable reliability with a Cronbach's alpha of .83 .

\section{DATA ANALYSIS}

For each of the variable measures, individual items for the measure were averaged to determine a single score for each subject. Means, standard deviations, minimums and maximums for each measure are shown in Table 1. Likert-measured items all used 5-point scales, while GPA was measured on a 4.0-scale. A 3.0 GPA was required for program admission. A correlation matrix for all of the items is shown in Table 2. To test the hypotheses, the covariance matrix for the resulting variable scores was subjected to a path analysis using Lisrel 8 and the method described by Joreskog \& Sorbom (1993). In addition to the paths necessary to test the hypotheses, consistent with Macon (1994), correlations between the three time management behavior components and between the dependent variable measures of satisfaction with the accounting major and academic performance were also included in the model. 
TABLE 1

DESCRIPTIVE STATISTICS

\begin{tabular}{|l|c|c|c|c|}
\hline & Mean & $\begin{array}{c}\text { Standard } \\
\text { Deviation }\end{array}$ & Minimum & Maximum \\
\hline Locus of control & 3.81 & 0.42 & 2.75 & 4.81 \\
\hline Time pressure on exams & 3.86 & 0.87 & 1.00 & 5.00 \\
\hline Desire for structure & 3.52 & 0.64 & 1.75 & 4.75 \\
\hline $\begin{array}{l}\text { Response to lack of } \\
\text { structure }\end{array}$ & 3.21 & 0.65 & 1.86 & 4.71 \\
\hline $\begin{array}{l}\text { Preference for } \\
\text { organization }\end{array}$ & 3.93 & 0.66 & 1.63 & 5.00 \\
\hline $\begin{array}{l}\text { Setting goals and } \\
\text { priorities }\end{array}$ & 3.49 & 0.63 & 1.80 & 5.00 \\
\hline $\begin{array}{l}\text { Mechanics of time } \\
\text { management }\end{array}$ & 3.20 & 0.64 & 1.64 & 4.55 \\
\hline Perceived control of time & 3.26 & 0.60 & 1.80 & 4.80 \\
\hline Performance (GPA) & 3.49 & 0.39 & 2.00 & 4.00 \\
\hline Satisfaction & 3.80 & 0.74 & 1.80 & 5.00 \\
\hline
\end{tabular}

TABLE 2

CORRELATION MATRIX

\begin{tabular}{|c|c|c|c|c|c|c|c|c|c|c|}
\hline & lc & tp & ds & rls & org & gp & mech & pc & gpa & sat \\
\hline Locus of control (lc) & 1.00 & $(.14)$ & .13 & .02 & .37 & .34 & .21 & .36 & .13 & .36 \\
\hline $\begin{array}{l}\text { Time pressure on exams } \\
\text { (tp) }\end{array}$ & & 1.00 & .15 & .17 & .01 & $(.01)$ & .07 & $(.10)$ & $(.20)$ & $(.11)$ \\
\hline Desire for structure (ds) & & & 1.00 & .57 & .42 & .23 & .32 & .12 & $(.02)$ & .09 \\
\hline $\begin{array}{l}\text { Response to lack of } \\
\text { structure (rls) }\end{array}$ & & & & 1.00 & .28 & .07 & .22 & $(.03)$ & $(.07)$ & .03 \\
\hline $\begin{array}{l}\text { Preference for } \\
\text { organization (org) }\end{array}$ & & & & & 1.00 & .42 & .59 & .48 & .08 & .35 \\
\hline $\begin{array}{l}\text { Setting goals and } \\
\text { priorities }(\mathrm{gp})\end{array}$ & & & & & & 1.00 & .65 & .41 & .16 & .38 \\
\hline $\begin{array}{l}\text { Mechanics of time } \\
\text { management (mech) }\end{array}$ & & & & & & & 1.00 & .36 & .11 & .34 \\
\hline $\begin{array}{l}\text { Perceived control of } \\
\text { time (pc) }\end{array}$ & & & & & & & & 1.00 & .09 & .41 \\
\hline Performance (gpa) & & & & & & & & & 1.00 & .16 \\
\hline Satisfaction (sat) & & & & & & & & & & 1.00 \\
\hline
\end{tabular}

The completed model exhibits a good fit with the observed data. Chi-square, which is commonly used to test the absolute level of goodness of fit for structural equations models, is 21.54 with $20 \mathrm{df}$ and $\mathrm{p}=.37$. This suggests that the observed covariance matrix does not differ significantly from the hypothesized matrix (Hair, Anderson, Tatham and Black, 1992) and is thus a good fit. Other measures of also exhibit good fit, with root mean square residual, which describes the amount of error per degree of freedom, at .027 , the goodness of fit index at .96, Bentler \& Bonett's normed fit index at .93, Bentler \& Bonett's nonnormed fit index at .98 and Bentler's comparative fit index at .99 . These statistics have recommended values of less than .05 for the root mean square residual and greater than .90 for the remaining measures (Hair, Anderson, Tatham and Black, 1992). 
FIGURE 2

RESULTS $^{1}$

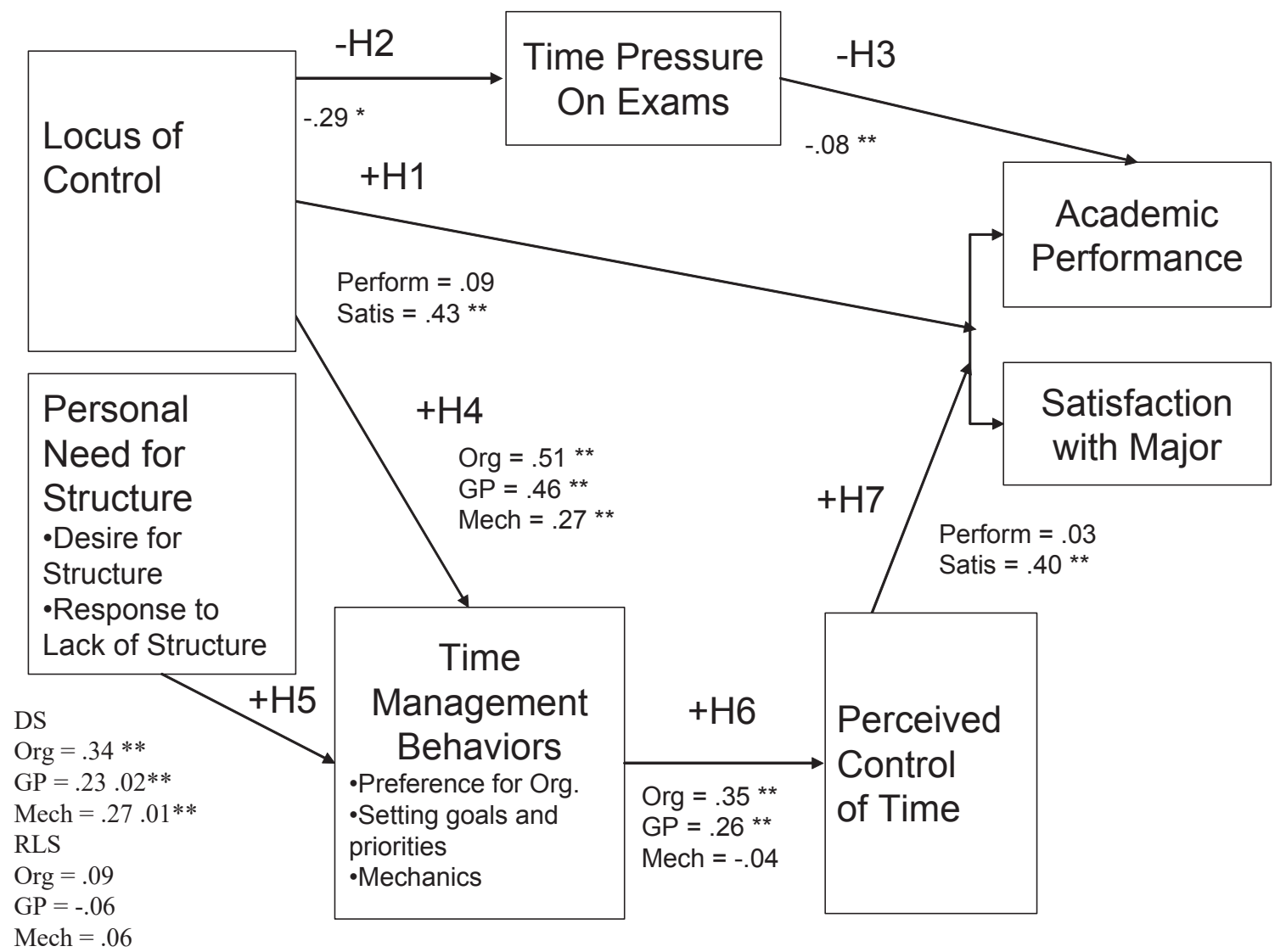

Adjusted GFI $=.90$

Bentler \& Bonett's NFI $=.93$

Bentler \& Bonett's NNFI $=.98$

Bentler's CFI: 99

Chi-Square $=21.54,20 \mathrm{df}, \mathrm{p}=.37$

RMSR $=.027$ 
TABLE 3

STRUCTURAL EQUATION MODELING RESULTS

\begin{tabular}{|l|l|c|c|c|c|}
\hline $\begin{array}{c}\text { Independent } \\
\text { Variable }\end{array}$ & $\begin{array}{c}\text { Dependent } \\
\text { Variable }\end{array}$ & $\begin{array}{c}\text { Associated } \\
\text { Hypothesis }\end{array}$ & $\begin{array}{c}\text { Path } \\
\text { Coefficient }\end{array}$ & t-statistic & p-value \\
\hline LC & Perfor & H1 & .09 & 0.96 & .17 \\
\hline & Satis & H1 & .43 & 2.77 & .01 \\
\hline TP & TP & H2 & $(.29)$ & 1.47 & .08 \\
\hline LC & Perform & H3 & $(.08)$ & 1.90 & .04 \\
\hline & Org & H4 & .51 & 4.10 & .01 \\
\hline & GP & H4 & .46 & 3.47 & .01 \\
\hline DS & Mech & H4 & .27 & 1.92 & .04 \\
\hline & Org & H5 & .34 & 3.25 & .01 \\
\hline & GP & H5 & .23 & 2.10 & .02 \\
\hline RLS & Mech & H5 & .27 & 2.39 & .01 \\
\hline & Org & H5 & .09 & 0.90 & .19 \\
\hline & GP & H5 & $. .06)$ & 0.62 & .27 \\
\hline Org & Mech & H5 & .06 & 0.59 & .28 \\
\hline GP & PC & H6 & .35 & 3.79 & .01 \\
\hline Mech & PC & H6 & .26 & 2.53 & .01 \\
\hline PC & PC & H6 & $. .04)$ & 0.34 & .37 \\
\hline & Perform & H7 & .03 & 0.43 & .34 \\
\hline
\end{tabular}

Given the excellent fit of the model, individual path coefficients, which are provided in Figure 2, can be examined in order to test the hypotheses as shown in Table 3. A significant positive relationship exists between locus of control and satisfaction with the accounting major $(.43, \mathrm{p}<.01)$, providing support for H1A. The relationship between locus of control and academic performance is not significant, yielding no support for H1B. Regarding hypothesis 2 and 3, a marginally significant relationship exists between locus of control and time pressure $(-.29, \mathrm{p}=.08)$, while a significant relationship exists between time pressure and performance $(-.08, \mathrm{p}=.04)$. Regarding hypothesis 4 , locus of control is significantly related to all three time management behaviors, preference for organization $(.51, \mathrm{p}<.01)$, setting goals and priorities $(.46$, $\mathrm{p}<.01)$, and mechanics $(.27, \mathrm{p}=.04)$.

In relation to hypothesis 5, a significant relationship exists between desire for structure and all three of the time management behaviors, preference for organization $(.34, \mathrm{p}<.01)$, setting goals and priorities $(.23 \mathrm{p}=.02)$, and mechanics $(.27 \mathrm{p}=.01)$. On the other hand, response to lack of structure is not significantly related to any of the three time management behaviors.

Results from the path analysis support two of the three paths in Macon's model positing a relationship between the time management behaviors and perceived control of time (hypothesis 6). A significant positive relationship exists between perceived control of time and preference for organization $(.35 \mathrm{p}<.01)$ and setting goals and priorities $(.26 \mathrm{p}=.01)$ and perceived control of time, but not for mechanics. Therefore, hypothesis 6 is only partially supported. A significant relationship exists between perceived control of time and satisfaction with the accounting major $(.40, \mathrm{p}<.01)$, providing support for H7A. The relationship between perceived control of time and academic performance, however, is not significant, yielding no support for H7B. 


\section{CONCLUSIONS}

Although the study suffers from common limitations of self-report survey-style work including a limited sample and the potential for demand effects, results significant enough to draw preliminary conclusions do emerge. All seven of the hypothesized links shown in Figure 1 are supported or partially supported. Consequently, we at least tentatively conclude that locus of control is an important correlate of satisfaction with the accounting major, both directly and indirectly through its influence on time management behaviors such as preference for organization, setting goals and priorities and other mechanics of time management. These time management behaviors in turn influence perceived control of time and then satisfaction with the accounting major. The importance of locus of control is underscored by looking at the total effect of locus control on satisfaction. This total effect is determined by adding both the direct and indirect effects on the dependent variable. The effect is $.54(t=3.54, p=.01)$, suggesting that a 1-point change in locus of control toward internal will result in a .54 increase in satisfaction with the accounting major (both measured on a 5-point scale). Desire for structure has a smaller, but also significant indirect influence on satisfaction visa vis its influence on time management behaviors and perceived control of time (total effect $=.07, \mathrm{t}=2.32, \mathrm{p}=.02$ ). On the other hand, response to lack of structure does not appear to be related to time management behaviors. The only factor from our model exhibiting a significant relationship with academic performance (measured in terms of GPA) was perceived time pressure on tests.

These results can guide accounting educators in a number of ways. First, as advisors to potential accounting students, educators may choose to recognize the importance of both locus of control and desire for structure on satisfaction with accounting as a major. Helping students to recognize the degree of fit between their personality and some of the demands that may be placed on them during an accounting program may help in managing expectations. Additionally, programs may choose to take measures to help better accommodate students with an external locus of control and low desire for structure through program modification or counseling.

Our model reinforces the findings of Macan, Shashandi, Dipboye and Phillips (1990), suggesting that time management behaviors, specifically preference for organization and setting goals and priorities, influence perceived control of time, which in turn influences satisfaction. The total indirect effect of these factors is not as striking as for locus of control (total effect for preference for organization $=.14, \mathrm{t}=2.64$, $\mathrm{p}=.01$; total effect for goals and priorities $=.11, \mathrm{t}=2.09, \mathrm{p}=.03)$, but is nonetheless significant enough to warrant efforts to help students make improvements. In particular, the relationships identified in our model suggest that efforts might be most fruitful with students with higher desire for structure or internal locus of control who might be more amenable to developing these behaviors but have never learned the appropriate skills.

The finding that perceived control of time is related to satisfaction with the accounting major has important implications, suggesting that students who perceive that they are able to control their time allocations believe they are a good fit with their chosen career paths. Should this perception carry over to their careers, as prior research would suggest (Macan, 1994), this result implies that those students who perceive the ability to control their time will feel greater job satisfaction once employed, suggesting less likelihood of turnover. This further emphasizes the need to help students learn time management behaviors.

\section{ENDNOTE}

1. indicates significant at alpha $=.10, * *$ indicates significant at alpha $=.05$ 


\section{REFERENCES}

Abbott, A. (1998). The system of professions. Chicago: Chicago University Press.

Ackerman, D. S., \& Gross, B. L. (2003). Is time pressure all bad? Measuring the relationship between free time availability and student performance and perceptions. Marketing Education Review, 13(2), 21-32.

Anderson, C. R., \& Schneier, C. E. (1978). Locus of control, leader behavior and leader performance among management students. Academy of Management Journal, 21, 690-698.

Anderson-Gough F., Grey, C., \& Robson, K. (2001). Tests of time: organizational time-reckoning and the making of accountants in two multi-national accounting firms. Accounting Organizations and Society, 26(2), 99-120.

Andrews, F. M., \& Farris, G. F. (1972). Time pressure and performance of scientists and engineers: a five-year panel study. Organizational Behavior and Human Performance, 8, 185-200.

Bartlett, T. (2002, February). Freshmen pay, mentally and physically, as they adjust to life in college. The Chronicle of Higher Education, 1, A35.

Bassett, G. A. (1979). A study of the effects of task goal and schedule choice on work performance. Organizational Behavior and Human Performance, 24, 202-227.

Bernardi, R. (1998). The relationships among locus of control, perception of stress, and performance. Journal of Applied Business Research, 13, 1-8.

Bierstaker, J. L., Howe, M., \& Seol, I. (2004). Accounting majors' perceptions regarding the 150-hour rule. Issues in Accounting Education, 19(2), 211-227.

Blau, G. (1993). Testing the relationship of locus of control to different performance dimensions. Journal of Occupational and Organizational Psychology, 66, 125-138.

Braun, R.E. (2000). The effect of time pressure on auditor attention to qualitative aspects of misstatements indicative of potential fraudulent financial reporting. Accounting, Organizations and Society, 25, 243-259.

Brown, C., \& Solomon, I. (1992). Auditors' judgments/decisions under time-pressure: an agenda for research and an illustration. In R. Srivastava (Ed.), Auditing Symposium XI: Proceedings of the 1992 Deloitte and Touche - University of Kansas Symposium on Auditing Problems. Lawrence, KS: University of Kansas.

Choo, F. (1995). Auditors' judgment performance under stress: a test of the predicted relationship by three theoretical models. Journal of Accounting, Auditing \& Finance, 10(3), 611-641.

Cummins, R. (1988). Perceptions of social support, receipt of supportive behaviors, and locus of control as moderators of the effects of chronic stress. American Journal of Community Psychology, 16, 685-699.

DuCette, J., \& Wolk, S. (1973). Cognitive and motivational correlates of generalized expectancies for control. Journal of Personality and Social Psychology, 26, 420-426.

Evans, B. J., \& Coman, C. J. (1993, January). General versus specific measures of occupational stress: an Australian police survey. Stress Medicine, 11-20.

Glover, S. M. (1997). The influence of time pressure and accountability on auditors' processing of nondiagnostic information. Journal of Accounting Research, 35(2), 213-226.

Hair, J.F., Anderson, R. E., Tatham, R. L., \& Black, W. C. (1992). Multivariate Data Analysis. New York, NY: Macmillan Publishing Company.

Jennings, B. M. (1990, December). Stress, locus of control, social support, and psychological symptoms among head nurses. Research in Nursing and Health, 393-401.

Joreskog, K., \& Sorbom, D. (1993). Lisrel 8: Structural Equation Modeling with SIMPLIS Command Language. Scientific Software International, Inc: Chicago.

Kelly, J. R., \& McGrath, J. E. (1985). Effects of time limits and task types on task performance and interaction of four-person groups. Journal of Personality and Social Psychology, 49(2), 395-407.

Kobasa, C., Maddi, S., \& Kahn, S. (1982). Hardiness and health: a prospective study. Journal of Personality and Social Psychology, 42, 168-177. 
Lakein, A. (1973). How to Get Control of Your Time and Your Life. New York: New American Library.

Latham, G. P., \& Locke, E. A. (1975). Increasing productivity with decreasing time limits: A field replication of Parkinson's Law. Journal of Applied Psychology, 60, 524-526.

Lawler, E. E. (1971). Pay and Organizational Effectiveness: A Psychological View. New York: McGrawHill.

Lefcourt, H. M., \& Wine, J. (1969). Internal versus external control of reinforcement and the deployment of attention in experimental situations. Canadian Journal of Behavioral Science, 1, 167-181.

Leone, C., Wallace, H. M., \& Modglin, K. (1999). The need for closure and the need for structure: Interrelationships, correlates, and outcomes. Journal of Psychology, 133(5),553-562.

Macan, T. H. (1994). Time management: test of a process model. Journal of Applied Psychology, 79(3), 381-391.

Macan, T. H., Shahani, C., Dipboye, R. L., \& Phillips, A. P. (1990). College students' time management: correlations with academic performance and stress. Journal of Educational Psychology, 82, 760768.

Majumder, R. K., MacDonald, A. P., \& Greever, K. B. (1977). A study of rehabilitation counselors: locus of control and attitudes toward the poor. Journal of Counseling Psychology, 24, 137-141.

McDaniel, L.S. (1990). The effects of time pressure and audit program structure on audit performance. Journal of Accounting Research, 28, (2), 267-285.

Neuberg, S. L., \& Newsom, J. T. (1993). Personal need for structure: individual differences in the desire for simple structure. Journal of Personality and Social Psychology, 65(1), 113-131.

Newmark, R. I., \& Karim, K. E. (2002). The effects of red-flag items, unfavorable projection errors, and time pressure on tax preparers' aggressiveness. Advances in Accounting Behavioral Research, 5, 213-243.

Otley, D. T., \& Pierce, B. J. (1996). Auditor time budget pressure: consequences and antecedents. Accounting, Auditing \& Accountability, 9(1), 31-58.

Peters, L. H., O‘Connor, E. J., Pooyon, A., \& Quick, J. C. (1984). The relationship between time pressure and performance: a field test of Parkinson's Law. Journal of Occupational Behavior, 5, 293-299.

Phares, E. J. (1968). Differential utilization of information as a function of internal-external control. Journal of Personality, 36, 649-662.

Phares, E. J. (1976). Locus of control in personality. Morristown, NJ: General Learning Press.

Ponemon, L. A. (1992). Auditor underreporting of time and moral reasoning: an experimental lab study. Contemporary Accounting Research, 9(1), 171-189.

Rahim, M., \& Psenicka, C. (1996). A structural equations model of stress, locus of control, social support, psychiatric symptoms, and propensity to leave a job. The Journal of Social Psychology, 136, 6984.

Rotter, J. B. (1954). Social learning and clinical psychology. New York, Prentice-Hall, 1954.

Rotter, J. B. (1966). Generalized expectancies for internal versus external control of reinforcement. Psychological Monographs 80: whole no. 609.

Schuler, R. S. (1980). Definition and conceptualization of stress in organizations. Organizational Behavior and Human Performance, 25, 184-215.

Spector, P. E. (1982). Behavior in organizations as a function of employee's locus of control. Psychological Bulletin, 91, 482-497.

Spector, P. E. (1988). Development of the work locus of control scale. Journal of Occupational Psychology, 61, 335-340.

Spilker, B. C. (1995). The effects of time pressure and knowledge on key word selection behavior in tax research. Accounting Review, 70(1), 49-70.

Spilker, B. C., \& Prawitt, D. F. (1997). Adaptive responses to time pressure: the effects of experience on tax information search behavior. Behavioral Research in Accounting, 9, 172-198.

Sweeney, J. T., \& Summers, S. L. (2002). The effect of busy season workload on public accountants' job burnout. Behavioral Research in Accounting, 14, 223-245. 
Thompson, M. M., Naccarato, N. E., \& Parker, K. E. (1989). Assessing cognitive need: the development of the personal need for structure and the personal fear of invalidity scales. Paper presented at the Annual Meeting of the Canadian Psychological Association, Halifax, Nova Scotia.

Thompson, M. M., Naccarato, N. E., \& Parker, K. E. (1992). Measuring cognitive needs: the development and validation of the personal need for structure (PNS) and personal fear of invalidity (PFI) measures. Working Paper.

Waggoner, J. B., \& Cashell, J. D. (1991). The impact of time pressure on auditors' performance. Ohio CPA Journal, 50(1), 27-32.

Wolk, S., \& DuCette, J. (1974). Intentional performance and incidental learning as a function of personality and task dimensions. Journal of Personality and Social Psychology, 29, 90-101.

Yukl, G. A., \& Latham, G. P. (1978). Interrelationships among employee participation, individual differences, goal difficulty, goal acceptance, goal instrumentality, and performance. Personnel Psychology, 31, 305-323. 


\section{APPENDIX}

\section{RESEARCH MEASURES}

\section{Time Pressure on Exams}

The following statements relate to the impact that time pressure on tests has on student performance. Please indicate the extent of your agreement with each statement using the following rating scale.

Mark a if the statement is definitely false or you Strongly Disagree

Mark b if the statement is mostly false or you Disagree

Mark c if the statement is equally true or false, or if you cannot decide, or if you are Neutral on the statement

Mark d if the statement is mostly true or you Agree

Mark e if the statement is definitely true or you Strongly Agree

\begin{tabular}{|ll|}
\hline 1. When I take a test time pressure does not bother me. (reverse scored) \\
\hline 2. & $\begin{array}{l}\text { I believe time pressure on a test causes a greater negative effect on my test grade than on } \\
\text { the test results of the other student in the class. }\end{array}$ \\
\hline 3. My level of test anxiety increases dramatically when I know the teacher's tests are hard \\
to complete in the time allowed.
\end{tabular}

\section{Satisfaction with Your Academic Major}

The following statements relate to your level of satisfaction with your current academic major. Please indicate the extent of your agreement with each statement using the following rating scale.

Mark a if the statement is definitely false or you Strongly Disagree

Mark b if the statement is mostly false or you Disagree

Mark c if the statement is equally true or false, or if you cannot decide, or if you are Neutral on the statement

Mark d if the statement is mostly true or you Agree

Mark e if the statement is definitely true or you Strongly Agree

1. I like the kind of class work I am doing in my major.

2. I am satisfied with my current academic major.

3. I often think of changing my major. (reverse scored)

4. As I progress in my major I think each step is more satisfying.

5. Most of my peers with the same major are satisfied with their major.

\section{Personal Need for Structure Scale (from Neuberg and Newsom, 1993)}

Read each of the following statements and decide how much you agree with each according to your attitudes, beliefs, and experiences. It is important for you to realize that there are no "right" or "wrong" answers to these questions. People are different, and we are interested in how you feel. Please respond according to the following scale.

Mark a if the statement is definitely false or you Strongly Disagree

Mark b if the statement is mostly false or you Disagree

Mark c if the statement is equally true or false, or if you cannot decide, or if you are Neutral on the statement

Mark d if the statement is mostly true or you Agree 
1. It upsets me to go into a situation without knowing what I can expect from it.

2. I'm not bothered by things that interrupt my daily routine. (reverse scored)

3. I enjoy having a clear and structured mode of life.

4. I like to have a place for everything and everything in its place.

5. I enjoy being spontaneous. (reverse scored)

6. I find that a well-ordered life with regular hours makes my life tedious. (reverse scored)

7. I don't like situations that are uncertain.

8. I hate to change my plans at the last minute.

9. I hate to be with people who are unpredictable.

10. I find that consistent routine enables me to enjoy life more.

11. I enjoy the exhilaration of being in unpredictable situations. (reverse scored)

12. I become uncomfortable when the rules in a situation are not clear.

\section{Locus of Control (from Spector, 1988)}

The following statements identify relationships rewards/outcomes and their causes. Please indicate the extent of your agreement with each statement using the following rating scale. Mark your answers on the answer sheet provided.

Mark a if the statement is definitely false or you Strongly Disagree

Mark b if the statement is mostly false or you Disagree

Mark c if the statement is equally true or false, or if you cannot decide, or if you are Neutral on the statement

Mark d if the statement is mostly true or you Agree

Mark e if the statement is definitely true or you Strongly Agree

1. A job is what you make of it.

2. On most jobs, people can pretty much accomplish whatever they set out to accomplish.

3. If you know what you want out of a job, you can find a job that gives that to you.

4. If employees are unhappy with a decision made by their boss, they should do something about it.

5. Getting the job you want is mostly a matter of luck. (reverse scored)

6. Making money is primarily a matter of good fortune. (reverse scored)

7. Most people are capable of doing their jobs well if they make an effort.

8. In order to get a really good job you need to have a family member or friends in high places. (reverse scored)

9. Promotions are usually a matter of good fortune. (reverse scored)

10. When it comes to landing a really good job, who you know is more important than what you know. (reverse scored)

11. Promotions are given to employees who perform well on the job.

12. To make a lot of money you have to know the right people. (reverse scored)

13. It takes a lot of luck to be an outstanding employee at most jobs. (reverse scored)

14. People who perform their jobs well generally get rewarded for it.

15. Most employees have more influence on their supervisors than they think.

16. The main difference between people who make a lot of money and people who make a little money is luck. (reverse scored) 


\section{Time Management Behaviors (from Macon, Shashani, Dipboye and Phillips, 1994)}

To what extent do each of the statements on the following pages accurately describe your activities and experiences in your work or school? Indicate how accurately each statement describes you by choosing ONE of the alternatives on the scale below and mark your answer on the answer sheet provided. THIS IS NOT A TEST. THERE ARE NO RIGHT OR WRONG ANSWERS. Please respond to all the times.

Mark a if the statement is Seldom True

Mark b if the statement is Occasionally True

Mark c if the statement is True about as often as not, or you are neutral

Mark d if the statement is Frequently True

Mark e if the statement is Very Often True

\begin{tabular}{|c|c|}
\hline \multirow{5}{*}{$\begin{array}{l}\text { Perceived } \\
\text { Control of } \\
\text { Time }\end{array}$} & $\begin{array}{l}\text { 1. I underestimate the time that it will take to accomplish tasks. (reverse } \\
\text { scored) }\end{array}$ \\
\hline & 2. I feel in control of my time. \\
\hline & 3. I must spend a lot of time on unimportant tasks. (reverse scored) \\
\hline & $\begin{array}{l}\text { 4. I find it difficult to keep to a schedule because others take me away from } \\
\text { my work. (reverse scored) }\end{array}$ \\
\hline & $\begin{array}{l}\text { 5. I find myself procrastinating on tasks that I don't like but that must be } \\
\text { done. (reverse scored) }\end{array}$ \\
\hline
\end{tabular}

\begin{tabular}{|c|c|}
\hline \multirow{10}{*}{$\begin{array}{l}\text { Setting } \\
\text { Goals and } \\
\text { Priorities }\end{array}$} & $\begin{array}{l}\text { 1. When I decide on what I will try to accomplish in the short term, I keep in } \\
\text { mind my long-term objectives. }\end{array}$ \\
\hline & 2. I review my goals to determine if they need revising. \\
\hline & 3. I break complex, difficult projects down into smaller manageable tasks. \\
\hline & 4. I set short-term goals for what I want to accomplish in a few days or weeks. \\
\hline & 5. I set deadlines for myself when I set out to accomplish a task. \\
\hline & $\begin{array}{l}\text { 6. I look for ways to increase the efficiency with which I perform my work } \\
\text { activities. }\end{array}$ \\
\hline & 7. I finish top priority tasks before going on to less important ones. \\
\hline & 8. I review my daily activities to see where I am wasting time. \\
\hline & $\begin{array}{l}\text { 9. During a workday I evaluate how well I am following the schedule I have } \\
\text { set down for myself. }\end{array}$ \\
\hline & ch I will per \\
\hline
\end{tabular}




\begin{tabular}{|c|c|}
\hline \multirow{11}{*}{$\begin{array}{l}\text { Mechanics } \\
\text { of Time } \\
\text { Management }\end{array}$} & 1. I carry a notebook to jot down notes and ideas. \\
\hline & 2. I schedule activities at least a week in advance. \\
\hline & $\begin{array}{l}\text { 3. When I find that I am frequently contacting someone, I record that } \\
\text { person's name, address, and phone number in a special file. }\end{array}$ \\
\hline & 4. I block out time in daily schedule for regularly scheduled events. \\
\hline & 5. I write notes to remind myself of what I need to do. \\
\hline & $\begin{array}{l}\text { 6. I make a list of things to do each day and check off each task as it is } \\
\text { accomplished. }\end{array}$ \\
\hline & 7. I carry an appointment book with me. \\
\hline & 8. I keep a daily log of my activities. \\
\hline & 9. I use an in-basket and out-basket for organizing paperwork. \\
\hline & $\begin{array}{l}\text { 10. I find places to work that will allow me to avoid interruptions and } \\
\text { distractions. }\end{array}$ \\
\hline & $\begin{array}{l}\text { 11. If I know I will have to spend time waiting, I bring along something I can } \\
\text { work on. }\end{array}$ \\
\hline
\end{tabular}

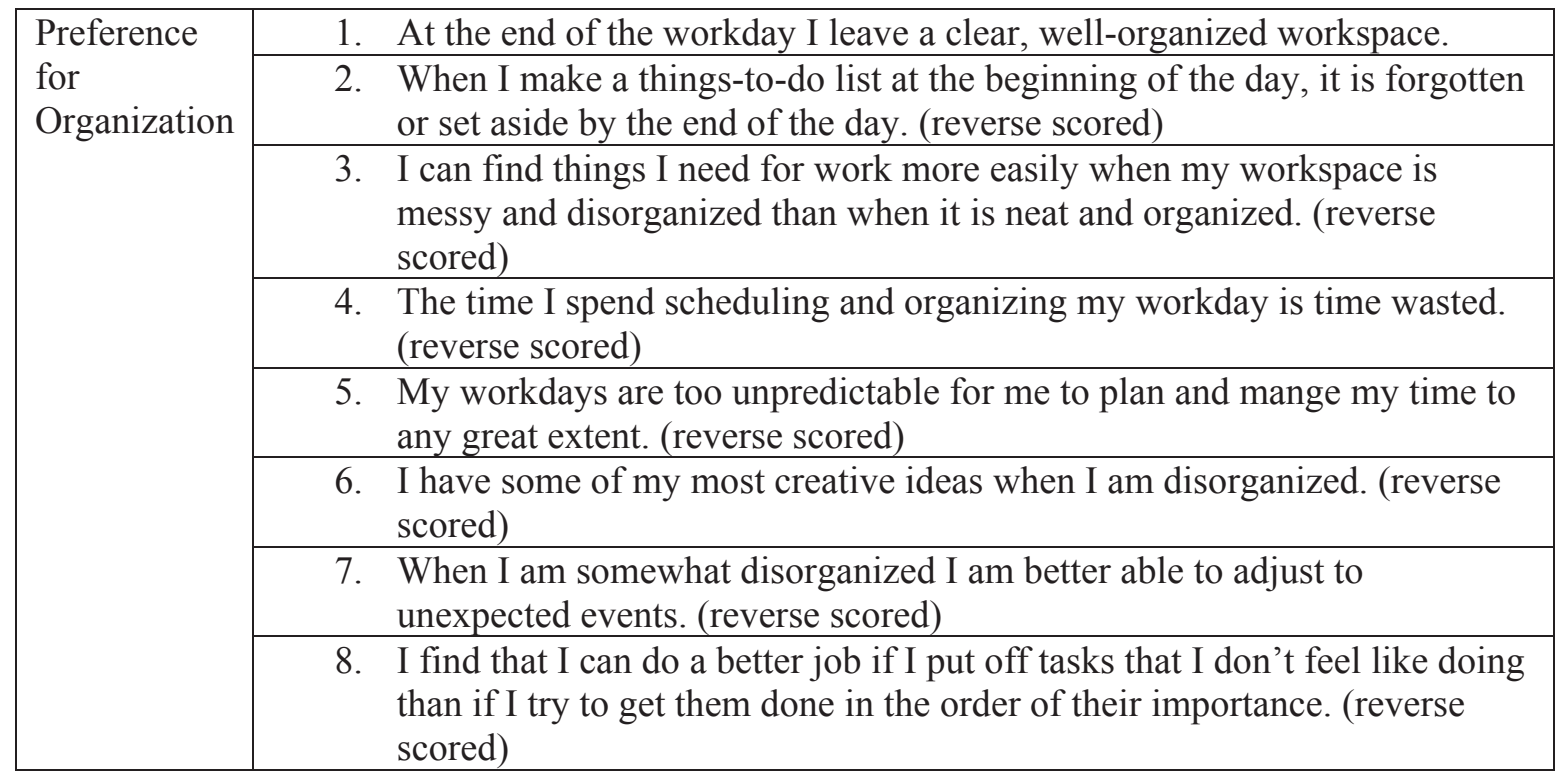

